\title{
Upper vena cava syndrome secondary to giant atrial myxoma
}

\author{
Flávia Contreira Longatto ${ }^{1}$ \\ Thamires Suellen Alves Pereira Santos ${ }^{1}$ \\ Marília Joaquina de Medeiros Soares ${ }^{1}$ \\ Juliana Negrisoli' \\ Tatiana de Carvalho Andreucci Torres Leal ${ }^{1}$ \\ Bruno Biselli ${ }^{1}$ \\ Múcio Tavares Oliveira Jr. ${ }^{1}$ \\ Alexandre de Matos Soeiro ${ }^{1}$
}

1. Clinical Emergency Unit - InCor - HCFMUSP - São Paulo, SP, Brasil

\section{SUMMARY}

Cardiac myxoma is a benign neoplasm, which corresponds to the most common primary heart tumour, responsible for about $50 \%$ of the cases. In general, 75-80\% of myxomas are located in the left atrium, 18\% in the right atrium, and more rarely in the ventricles or multicentric. Right atrial myxoma, in particular, can obstruct the tricuspid valve, causing symptoms of right heart failure, peripheral oedema, hepatic congestion, and syncope. Systemic embolization occurs in 30\% of cases, by either tumour fragmentation or total tumour detachment. In the present report, we present a case of a symptomatic patient, who showed a large right intra-atrial lesion, with consequent superior vena cava syndrome, and then underwent surgical resection at admission.

KEYWORDS: Myxoma. Venae cavae. Heart Neoplasms.

\section{INTRODUCTION}

Primary heart tumours are rare to be found. Of these, myxomas are the most common primary benign neoplasms of the heart and approximately $75 \%$ of them are located in the left atrium. Myxomas are more common among women and often occur between 30 and 60 years of age. The signs and symptoms may be nonspecific and with a predominance of constitutional symptoms, and may be manifested by symptoms arising from the obstruction of atrioventricular valves or embolization phenomena. ${ }^{1}$ Thus, diagnosis is rarely performed only by physical examination and clinical history. Presentation as superior vena cava syndrome is uncommon and rarely described in literature. ${ }^{2}$

A 55-year-old female, black patient admitted with a complaint of dyspnoea on minimal exertion and oedema of the face and upper limbs for 2 months. She reported a personal history of systemic arterial hypertension, haemorrhagic stroke 7 years ago and she was a former smoker. Physical examination found heart rate at 100 beats per minute, blood pressure of $130 \times 70 \mathrm{mmHg}$, respiratory

DATE OF SUBMISSION: 27-Mar-2018

DATE OF ACCEPTANCE: 04-Apr-2018

CORRESPONDING AUTHOR: Alexandre de Matos Soeiro

Av. Dr. Eneas de Carvalho Aguiar, 44 - Cep 05403-900 - Cerqueira César, São Paulo, Brasil

Phone no.: +55 (11) 99913-4377

E-mail: alexandre.soeiro@bol.com.br 


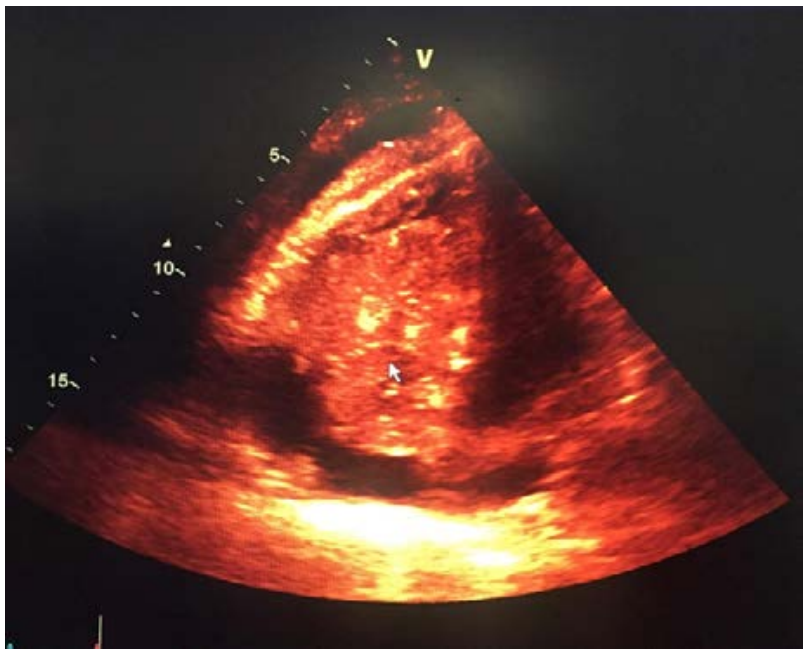

FIGURE 1. IMAGE OF TWO-DIMENSIONAL

TRANSTHORACIC ECHOCARDIOGRAPHY, SHOWING A LARGE AND IRREGULAR MASS IN THE RIGHT ATRIUM.

rate of 25 incursions per minute, arterial saturation $90 \%$ in ambient air, capillary filling time $<3$ $\mathrm{s}$, rhythmic and normophonetic sounds without murmurs, vesicular murmurs present with bibasilar crackles and oedema $+4 /+4$ on the face, upper limbs, cervical region and trunk. At that time, the diagnosis of superior vena cava syndrome and heart failure was made. Electrocardiogram showed sinus rhythm with diffuse alteration of ventricular repolarization. Transthoracic echocardiography revealed a large mass inside the right chambers $(8.0 \times 4.0 \mathrm{~cm})$, surface and irregular borders, very mobile, hyperechogenic, heterogeneous, passing through the tricuspid valve to the right ventricle, adhered to the interatrial septum (figure 1). Diagnostic hypothesis of superior vena cava syndrome due to intra-cardiac neoplasia. The patient was referred to the surgical centre for resection of the tumour, removing all the mass and the blade of the oval fossa, in addition to closing the intra-atrial communication. The surgical description reported excision of a giant tumour of the right atrium, with invasion of the right ventricle and intense restriction of that. The margins were macroscopically free of neoplastic involvement and the patient left cardiopulmonary bypass without difficulty after 33 minutes and with anoxia of 21 minutes. The resected material was sent to anatomopathological study and confirming the diagnosis of myxoma. In the postoperative period, the patient evolved uneventfully, being discharged from the intensive care unit on the $2^{\text {nd }}$ day. The oedema regressed sig-

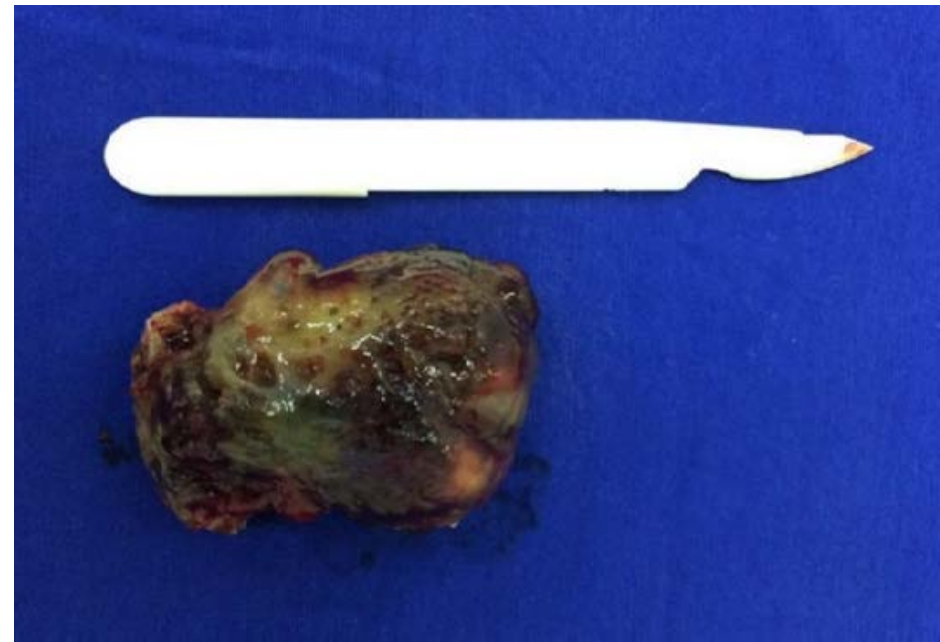

FIGURE 2. SAMPLE OBTAINED FROM THE PATIENT DURING SURGERY.

nificantly and she was discharged on the $5^{\text {th }}$ postoperative day.

\section{DISCUSSION}

Tumours that originate from the heart are rare, found in less than $0.1 \%$ of the population. Of the primary cardiac tumours, $80 \%$ are considered benign. Of these, myxoma is the most frequent one, constituting $50 \%$ of benign primary cardiac tumours. It occurs most often between 30 and 60 years of age and in females. It usually occurs sporadically, although family cases of multifocal location associated with Carney's syndrome are described. Fibroelastomas and papillary lipomas are other types of benign cardiac tumours in adults but rarer than myxomas. ${ }^{3}$ In the case reported above, it occurred in a 55-year-old woman with no records of similar cases in the family.

Cardiac myxomas are usually pedunculated, with fixation of the fibrovascular stem to the subendothelial base. The common site of fixation is the interatrial septum, in the region of the oval fossa. In contrast to other cardiac tumours, such as lipoma and rhabdomyoma, which are typically not pedunculated. ${ }^{4}$

Rarely the cardiac myxoma can directly involve the heart valves. Most have diameters ranging from 4 to $8 \mathrm{~cm}$, although their diameter can reach $16 \mathrm{~cm}$. Its average weight is of $37 \mathrm{~g}$ with variation of 15 to $180 \mathrm{~g}$. Approximately, half of myxomas have a villous surface. Evidence suggests that myxomas with villous surface are more likely to embolize. ${ }^{5}$ The tumour de- 
scribed in this case presented it $(8.0 \times 4.0 \mathrm{~cm})$, being already called giant myxoma (figure 2). The location was typical, however, obstruction of the tricuspid ring with manifestation of vena cava syndrome is what makes the case uncommon.

The most common clinical manifestations are constitutional or systemic, known as myxoma syndrome such as fatigue, fever, weight loss, arthralgia, myalgia, erythematous rash and laboratory abnormalities such as anaemia and elevated sedimentation rate, C-reactive protein and globulins, have been related in a discordant way with the size and the location of the tumour. It is believed that these manifestations are related to the production and release of IL- 6 by the tumour cells themselves, and it is also suggested the relation with phenomena of intratumoral haemorrhage, microembolism or the release of tumour fragments, which stimulate an immune response in the patient. In any case, the systemic manifestations resolve after removal of the tumor. ${ }^{6}$

Symptoms of intracardiac obstruction, heart failure, embolism, syncope or sudden death (due to complete mitral valve obstruction or coronary artery embolization) may also be present. Heart failure is more common in septum-related solid tumours, whereas systemic embolization is more frequent in papillary tumours of extra septal origin. ${ }^{7}$

In the case presented, the patient evolved with symptoms of heart failure such as dyspnoea at minimal progressive efforts and oedema of the face and upper limbs that suggested superior vena cava syndrome. Such obstruction can be caused by invasion or extrinsic compression by contiguous pathological processes involving the right lung, lymph nodes and other mediastinal structures, or by intraluminal thrombosis. ${ }^{5}$ The clinical manifestations of right atrial myxoma result mainly from tricuspid valve stenosis and pulmonary embolism. Tricuspid valve stenosis causes systemic venous congestion without pulmonary congestion while pulmonary embolism produces dyspnoea and pulmonary hypertension causing right heart failure. ${ }^{8}$

We did not find in the literature a similar report caused by myxoma. We believe that due to the mobility of the tumour, such manifestation usually does not occur since the obstruction to the flow would be intermittent. This form of presentation probably infers a greater degree of fixed obstruction and gravity.

Non-invasive methods, such as echocardiogra- phy and computed tomography of the chest, have made a great contribution to the diagnosis of intracardiac myxomas. In addition to confirming the diagnosis, they allow the establishment of the best surgical technique. ${ }^{9}$ Transthoracic echocardiography, although less invasive, has shown 95\% sensitivity in the detection of myxomas. ${ }^{10}$ In some cases clinical echocardiographic data may not collaborate in the distinction between structures, and may be aided by computed tomography of the chest and magnetic resonance imaging. The use of transesophageal echocardiography seems to provide additional and more accurate information regarding transthoracic echocardiography, including intraoperative echocardiography to better delineate the surgical margins. ${ }^{1}$

Another factor of fundamental importance is the investigation of all cardiac chambers. In addition to biatrial approach, biventricular approach may also be necessary, not only to avoid relapse, but also the risk of embolization. As in the case reported in which the tumour had originated in the right atrium with invasion of the right ventricle. ${ }^{9}$

Due to risks previously mentioned as risks of embolization, valvular or outflow tract obstruction and arrhythmogenesis, the most common treatment approach is surgery in patients with myxomas and the results are generally favourable. Therefore, surgical excision should be planned as soon as the diagnosis is confirmed. Thromboembolic events are rare postoperatively and atrial arrhythmias are the most common complications after surgery for myxoma removal. Myxomas can be resected with low early mortality and excellent long-term survival. Although tumour recurrence is rare, imaging follow-up is recommended because the recurrence rate is significantly higher in the first 10 years after surgery. ${ }^{1}$

\section{CONCLUSION}

The report of superior vena cava syndrome by atrial myxoma with tricuspid valve obstruction is unique. However, it is completely reversible after surgery.

\section{Conflict of interest}

The authors declare that they agree with the publication, have no conflicts of interest and do not have funding for the study in question. 


\section{RESUMO}

O mixoma cardíaco é uma neoplasia benigna, que corresponde ao tumor primário mais comum do coração, responsável por cerca de 50\% dos casos. De modo geral, 75 a 80\% dos mixomas estão localizados no átrio esquerdo, 18\% no átrio direito, e mais raramente, nos ventrículos ou multicêntricos. O mixoma atrial direito, em particular, pode obstruir a válvula tricúspide, causando sintomas de insuficiência cardíaca direita, edema periférico, congestão hepática e síncope. A embolização sistêmica ocorre em $30 \%$ dos casos, quer pela fragmentação do tumor ou pelo desprendimento total do mesmo. No presente relato, apresentamos um caso de uma paciente sintomática, que evidenciou grande lesão intra-atrial direita, com consequente síndrome da veia cava superior, sendo, então, submetida a ressecção cirúrgica na internação.

PALAVRAS-ChaVE: Mixoma. Veias cavas. Neoplasias Cardíacas.

\section{REFERENCES}

1. Kavakli AS, Kavrut Ozturk N. Determination of residual mass in left ventricle by intraoperative transesophageal echocardiography after a giant and floating left atrial myxoma resection. Rev Bras Anestesiol. 2017. pii: S0034-7094(17)30137-X

2. Pires NF, Morais A, Queiroga $H$. Superior vena cava syndrome as tumour presentation. Rev Port Pneumol. 2010,16(1):73-88.

3. Bowman |N, Treece |, Bhattad PB, Bochis M, Bajaj K. Giant left atrial myxoma masquerading as cough-syncope syndrome. J Investig Med High Impact Case Rep. 2017;5(3):2324709617724177.

4. Choi $\mathrm{CH}$, Park $\mathrm{CH}$, Kim JS, Jeon YB, Lee JI, Park KY. Giant biatrial myxoma nearly obstructing the orifice of the inferior vena cava. J Cardiothorac Surg. 2013;8:148.

5. Bonow RO, Mann D, Zipes D, Libby P. Braunwald's heart disease: a textbook of cardiovascular medicine. $9^{\text {th }}$ ed. Philadelphia:Saunders Elsevier; 2011.
6. Marta L, Peres M, Alves M, Ferreira da Silva G. Giant left atrial myxoma presenting as acute myocardial infarction. Rev Port Cardiol. 2012;31(12):815-9.

7. Kuroda T, Yokoyama Y, Yuhara S, Okawa H, Hasegawa H, Yokote J, et al. Giant biatrial myxoma with two different gross findings. Gen Thorac Cardiovasc Surg. 2018;66(6):358-60.

8. Nakabayashi $\mathrm{K}$, Murata S, Kato H, Oka T. The differentiation of giant right atrial myxoma from metastatic cancer with the use of multiple imaging modalities. Intern Med. 2016;55(8):925-8.

9. Dias RR, Stolf NA, Malbouisson LM, Fernandes F, Ramirez FI, Mady C, et al. Morbidity and embolic potential of left atrial cardiac tumors. Thorac Cardiovasc Surg. 2006;54(6):400-3.

10. Vale MP, Freire Sobrinho A, Sales MV, Teixeira MM, Cabral KC. Giant myxoma in the left atrium: case report. Rev Bras Cir Cardiovasc. 2008;23(2):276-8 